\title{
DINAMIKA COLLABORATIVE GOVERNANCE DALAM STUDI KEBIJAKAN PUBLIK
}

\author{
Ni Luh Yulyana Dewi \\ Universitas Pendidikan Nasional Denpasar \\ yulyanadewi@yahoo.com
}

\begin{abstract}
ABSTRAK
Dalam beberapa tahun terakhir, collaborative governance (tata kelola pemerintahan) menjadi salah satu konsep kepublikan yang mulai banyak diminati oleh para akademisi. Collaborative Governance muncul untuk merespon terjadinya kegagalan implementasi, biaya mahal dan politisasi regulasi sektor publik. Fokusnya mengarah pada setiap tahapan kebijakan publik. Collaborative governance merupakan sebuah paradigma baru dalam memahami eksistensi multi stakeholders dalam urusanurusan publik. Tulisan ini mendeskripsikan secara aktual tentang dinamika collaborative governance dalam studi kebijakan publik yang berkaitan dengan nilai dasar dari perspektif "new public governance" dalam menghadapi proses tahapan kebijakan. Kompleksnya hubungan antara aktor dalam kebijakan publik melahirkan konsep baru yang dinamakan collaborative governance. Ringkasnya, collaborative governance adalah proses dan struktur yang melibatkan berbagai pihak melintasi batas-batas organisasinya. Kolaborasi digunakan untuk menggambarkan kerjasama yang formal, aktif, eksplisit dan berorientasi kolektif dalam manajemen dan kebijakan publik. Adapun nilai dasarnya yakni orientasi konsensus dalam pengambilan keputusan (tujuan), kepemimpinan kolektif dalam kelembagaan (struktur), komunikasi multiarah dalam hubungan kemanusiaan (interaksi) dan berbagi sumber daya dalam aksi (proses). Nilai dasar tersebut menjadi satu kesatuan yang terintegrasi pada setiap tahapan kebijakan publik.
\end{abstract}

Kata Kunci: Kebijakan Publik, Governance, Collaborative Governance 


\begin{abstract}
In recent years, collaborative governance has become one of the publications concepts that academics have begun to take a lot of interest in. Collaborative Governance appears to respond to implementation failures, high costs and politicization of public sector regulations. The focus is on every stage of public policy. Collaborative governance is a new paradigm in understanding the existence of multi stakeholders in public affairs. This paper describes the actual dynamics of collaborative governance in the study of public policies relating to the basic values from the perspective of "new public governance" in dealing with the policy process process. The complexity of the relationship between actors in public policy gave birth to a new concept called collaborative governance. In summary, collaborative governance is a process and structure that involves various parties across organizational boundaries. Collaboration is used to describe formal, active, explicit and collective-oriented collaboration in management and public policy. The basic values are consensus orientation in decision making (goals), collective leadership in institutions (structures), multi-directional communication in human relations (interactions) and sharing of resources in action (processes). These basic values become an integrated whole at each stage of public policy.
\end{abstract}

Keywords: Public Policy, Governance, Collaborative Governance

\title{
PENDAHULUAN
}

Kerangka collaborative dalam governance memberikan suatu pemaknaan yang lebih dari sekedar governance. Collaborative governance merupakan salah satu konsep dalam kebijakan publik yang berkembang dalam beberapa dekade terakhir. Secara prinsip, collaborative (kolaborasi) berbeda dengan network (jaringan) dan partnership (kemitraan). Ada nilai dasar tersendiri yang melekat

padanya. Untuk selanjutnya menjadi bagian karakteristiknya. Akhir daripada pemikiran keritis mengenai paradigma NPM dan reinventing government adalah dengan diterapkannya good governance atau tata pemerintahan yang baik. NPS menilai bahwa NPM dan OPA terlalu menekankan kepada efisiensi dan melupakan masyarakat sebagai sasaran dari kebijakan publik. Governance merujuk kepada hubungan antara pemrintah/negara dengan warganya sehingga memungkinkan berbagai kebijakan dan program dapat dirumuskan, diimplementasikan, dan dievaluasi.

Pergeseran government ke governance dimaksudkan untuk mendemokratisasi administrasi publik. Government menunjuk kepada institusi pemerintah terutama dalam kaitannya dengan pembuatan kebijakan. Sementara itu, governance menunjuk kepada keterlibatan Non Governmental Organization (NGO), kelompok-kelompok kepentingan, dan masyarakat, disamping institusi pemerintah dalam pengelolaan kepentingan umum, terutama dalam perumusan dan pelaksanaan kebijakan publik. Berbagai kebijakan dan program 
diarahkan untuk memenuhi kepentingan warga masyarakat dan dilakukan melalui tindakan kolektif dan proses kolaboratif.

Menurut Osborne (2010) public governance berisi lima untaian sebagai berikut :

1. Socio-political governance: menyangkut hubungan antar institusi dalam masyarakat.

2. Public policy governance: berkaitan dengan bagaimana elite membuat kebijakan beserta jaringannya berinteraksi dalam proses pembuatan dan pelaksanaan kebijakan publik.

3. Administrastive governance: menyangkut efektivitas penerapan administrasi publik dan reposisinya untuk menangani masalah-masalah pemerintah.

4. Contract governance: berkaitan dengan penerapan NPM, dipandang perlu adanya kontrak perjanjian dalam penyelenggaraan pelayanan publik (perjanjian antara penyedia pelayanan publik dengan pihak penerima pelayanan). Organisasi publik pada negara-negara modern memiliki tanggung jawab untuk menyediakan sistem pelayanan publik yang baik.

5. Network governance: merupakan jaringan kerja sama mandiri antar organisasi pemerintah atau tanpa organisasi pemerintah dalam penyedia pelayanan publik.

Dalam beberapa tahun terakhir, collaborative governance (tata kelola pemerintahan) menjadi salah satu konsep kepublikan yang mulai banyak diminati oleh para akademisi. Collaborative Governance muncul untuk merespon terjadinya kegagalan implementasi, biaya mahal dan politisasi regulasi sektor publik (Ansell dan Gash, 2007). Fokusnya mengarah pada setiap tahapan kebijakan publik. Collaborative governance merupakan sebuah paradigma baru dalam memahami eksistensi multi stakeholders dalam urusan-urusan publik. Ada karakteristik tertentu dalam hubungan aktor sehingga penting melakukan studi kolaborasi (Silvia, 2011).

Berdasarkan uraian latar belakang di atas, melalui tulisan ini ingin mencermati bagaimana dinamika collaborative governance dalam studi kebijakan publik yang berkaitan dengan nilai dasar dari perspektif "new public governance". Tulisan ini terfokus bukan pada pengukuran baik secara kualitatif maupun kuantitatif, tetapi mendeskripsikan dan menjelaskan secara aktual, faktual mengenai dinamika collaborative governance dalam menghadapi proses tahapan kebijakan. 


\section{KAJIAN TEORI}

\section{Kebijakan Publik}

Kebijakan publik selalu menjadi isu sentral bagi banyak pihak karena dalam kebijakan publik melibatkan banyak pihak, baik secara langsung maupun secara tidak langsung dalam proses perumusan, implementasi ataupun dalam proses evaluasi daripada implementasinya.

Carl J Frederick sebagaimana dikutif oleh Leo Agustino (2008:7) mendefinisikan kebijakan sebagai rangkaian tindakan/kegiatan yang diusulkan seseorang, kelompok atau pemerintah dalam suatu lingkungan tertentu dimana terdapat hambatan-hambatan (kesulitankesulitan) dan kesempatan-kesempatan terhadap pelaksanaan usulan kebijaksanaan tersebut dalam rangka mencapai tujuan tertentu. Pendapat ini juga menunjukkan bahwa ide kebijakan melibatkan perilaku yang memiliki maksud dan tujuan yang penting dari definisi kebijakan, karena bagaimanapun kebijakan harus menunjukkan apa yang sesungguhnya dikerjakan daripada apa yang diusulkan dalam beberapa kegiatan pada suatu masalah. Mirip dengan definisi Carl J Frederick tersebut diatas, Anderson merumuskan kebijaksanaan sebagai langkah tindakan yang secara sengaja dilakukan oleh seorang aktor atau sejumlah aktor berkenaan dengan adanya masalah atau persoalan tertentu yang dihadapi, (Abdul Wahab,1997;3).

Solihin Abdul Wahab mengemukakan bahwa istilah kebijakan sendiri masih terjadi silang pendapat dan merupakan ajang perdebatan para ahli, maka untuk memahami istilah kebijakan, Solihin Abdul Wahab (2004:40-50) memberikan beberapa pedoman sebagai berikut:

1. Kebijakan harus dibedakan dari keputusan;

2. Kebijakan sebenarnya tidak serta dapat dibedakan dari administrasi;

3. Kebijakan mencakup prilaku dan harapan-harapan;

4. Kebijakan mencakup ketiadaan ataupun adanya tindakan;

5. Kebijakan biasanya mempunyai hasil akhir yang akan dicapai;

6. Setiap kebijakan memiliki tujuan atau sasaran tertentu baik eksplisit maupun implicit;

7. Kebijakan muncul dari suatu proses yang berlangsung sepanjang waktu;

8. Kebijakan meliputi hubungan-hubungan yang bersifat antar organisasi dan yang bersifat intraorganisasi; 
9. Kebijakan publik meski tidak ekslusif menyangkut peran kunci lembaga-lembaga pemerintah;

10. Kebijakan itu dirumuskan atau didefinisikan secara subyektif.

\section{Governance}

Governance adalah proses pembuatan kebijakan dimana kebijakan tersebut dilaksanakan melibatkan negara (pemerintah), sektor privat maupun masyarakat madani dalam proses pembuatan dan pelaksanaan kebijakan (Kurniawan, 2007, hlm. 16-17). Terdapat lima prosisi mengenai governance yaitu : 1) Governance merujuk kepada institusi dan aktor, 2) Governance mengindentifikasikan adanya kaburnya batas-batas dan tanggungjawab mengatasi isu sosial dan isu ekonomi, 3) Governance mengindentifikasikan adanya ketergantungan hubungan antara institusi terlibat, 4) Governance adalah mengenai self-governing otonom dari aktor-aktor, 5) Governance menyadarkan untuk memperbaiki sesuatu tidak perlu bergantung kepada kekuasaan pemerintah melalui perintah dan kewenangannya (Stoker dalam Kurniawan, 2007, hlm. 16).

Berdasarkan beberapa pengertian tersebut menurut peneliti, governance adalah proses pembuatan kebijakan yang dilakukan oleh penyelenggara pemerintah. Kebijakan yang ditetapkan membutuhkan kerjasama antar pihak terkait. Kerjasama tersebut meliputi pendekatan kolaborasi yaitu meliputi pemerintah, swasta dan masyarakat dalam mencapai tujuan yang telah disepakati sebelumnya.

\section{Collaborative Governance}

Kerjasama kolaboratif terjadi penyamaan visi, tujuan, strategi dan aktivitas antara para pihak tetapi memiliki otoritas untuk mengambil keputusan secara independen dan memiliki otoritas dalam mengelola organisasi walaupun mereka tunduk pada kesepakatan bersama (Dwiyanto, 2011, hlm.251). Collaborative Governance menekankan enam kriteria yaitu : (1) forum ini diprakarsai oleh lembaga publik atau lembaga, (2) peserta dalam forum termasuk aktor swasta, (3) peserta terlibat langsung dalam pengambilan keputusan dan bukan hanya sebagai penyedia layanan oleh agensi publik, (4) terorganisir, (5) forum bertujuan untuk membuat keputusan dengan konsensus dan (6) fokus kolaborasi ada pada kebijakan publik maupun manajemen publik (Ansell \& Gash, 2007, hlm.6). 
Berdasarkan pengertian tersebut, menurut peneliti collaborative governance adalah suatu kegiatan yang mengikat antar pihak-pihak terkait. Pihak tersebut merupakan mitra dan pather kerja untuk mencapai suatu tujuan sesuai dengan ketentuan dan kesepakatan bersama yang saling menguntungkan guna menghasilkan barang dan pelayanan.

\section{PEMBAHASAN}

Menurut Ansell dan Gash (2007: 547-548), jaringan digunakan untuk menggambarkan bentuk kerjasama pemerintah dengan masyarakat yang lingkupnya lebih plural, informal dan implicit. Kemitraan digunakan untuk menggambarkan kerjasama yang lebih berorientasi pada koordinasi daripada konsensus dalam pengambilan keputusan. Kolaborasi digunakan untuk menggambarkan kerjasama yang formal, eksplisit dan berorientasi kolektif dalam pengambilan keputusan. Kolaborasi melibatkan pengelolaan hubungan untuk memanipulasi regulasi dan sistem sementara jaringan hanya berbicara pada pelaksanaan pekerjaan sipil (Goliday, 2010). Kemitraan terjadi ketika agen private kurang lebih menggantikan peran publik sedangkan kolaborasi terjadi ketika agen public dan private melakukan fungsi-fungsi aktif (Bevir, 2009).

Collaborative governance sebagai bentuk new public governance mempunyai nilai dasar. Dengan kata lain, nilai dasar itulah yang menjadi penekanan yang penting dipahami untuk memudahkan dalam menganalisis suatu fenomena sekaligus membuat sebuah teori baru tentang administrasi dan kebijakan publik. Perlu ada pencerahan untuk memahami apakah fenomena yang ada berwujud collaborative governance atau tidak. Jangan sampai ada kekeliruan yang terjadi dalam kajian teoritik dan empirik. Melalui tulisan ini, dijelaskan empat nilai dasar dari collaborative governance yakni :

1. Orientasi Konsensus, poin ini menjelaskan tujuan collaborative governance. Ansell dan Gash (2007) dalam tulisannya yang berjudul 'Collaborative Governance In Theory and Practice', kriteria kolaborasi adalah konsensus. Persetujuan dilandasi pada kepentingan bersama. Konsensus harus dilandasi dengan komitmen. Muatan komitmen terkait dengan pengawalan janji atau kesepakatan. Tanpa komitmen yang tinggi, sulit mewujudkan kesatuan janji.

Disamping itu, hal yang menentukan sebuah konsensus tergantung pada 205 simbiosis mutualisme (saling menguntungkan). Apabila ada pihak yang dirugikan, 
peluang tidak tercapainya konsensus sangat besar. Jadi, saling komitmen dan saling menguntungkan penting dikedepankan agar orientasi dapat tercapai dengan baik. Memang tidak mudah mencapai pemufakatan bersama karena banyak kepentingan dalam sebuah collaborative governance. Berbeda organisasi terkadang berbeda kepentingan.

2. Kepemimpinan Kolektif, poin ini menjelaskan bentuk struktur kelembagaan collaborative governance.

Salah satu tema pokok dalam praktek kolaborasi menurut Osborne, Stephen. P (2010) adalah leadership (kepemimpinan). Emerson dkk (2011) menambahkan bahwa kepemimpinan merupakan bagian dari kapasitas aksi bersama dalam praktek collaborative governance. Kepemimpinan dalam kolaborasi lebih berbentuk jaringan daripada hierarki. Artinya, setiap pihak berada pada posisi yang sama. Hubungan pihak yang terlibat lebih pada fungsi koordinasi daripada komando. Berbeda dengan pola hierarki yang biasanya lebih mengedepankan komando. Posisi aktor sama secara struktural. Tidak ada yang berada diatas ataupun dibawah. Garis koordinasinya tidak vertikal. Masing-masing memiliki tugas yang berbeda tetapi berada pada posisi yang sama. Tugas dan tanggungjawab dilakukan secara berkala.

Pemahaman kepemimpinan dalam kolaborasi diarahkan pada kepemimpinan kolektif. Semua aktor invidu, kelompok atau organisasi yang terlibat berstatus pemimpin tanpa terkecuali. Istilah kepemimpinan kolektif senada dengan istilah distribusi kepemimpinan seperti yang dikemukakan oleh Martin dkk (2008). Meskipun diarahkan pada model kolektif, kehadiran koordinator tetap dianjurkan untuk memudahkan pengarahan. Setidaknya menjadi pusat dari tahapan kebijakan publik untuk mengetahui kemajuan, hasil dan dampak. Kepemimpinan kolektif berbasis jaringan menjadi salah satu nilai dasar. Kepemimpinan kolektif bentuk dari distribusi kekuatan diantara para pemangku kepentingan menurut Johnston dkk (2010).

3. Komunikasi Multiarah, poin ini menjelaskan interaksi antar aktor dalam proses collaborative governance.

Cline (2000) menyatakan bahwa komunikasi merupakan subsistem dari implementasi kebijakan. Dalam kolaborasi dibutuhkan adanya komunikasi multiarah. Komunikasi multiarah yakni adanya umpan balik yang berlangsung dengan melibatkan lebih dari 
dua pihak yang berlangsung secara berkelanjutan dengan intensitas yang tinggi. Respon dan tanggapan dilakukan pada semua pihak yang terlibat dengan berbagai macam cara berkomunikasi (lisan atau tulisan). Collaborative governance yang ideal setidaknya mengikutsertakan minimal dari tiga pihak. Ada representasi pemerintah, swasta dan masyarakat. Komunikasi yang dilakukan melalui tatap muka langsung. Komunikasi melalui media dilakukan hanya untuk membantu terjalinnya komunikasi intensif.

Komunikasi multiarah dijadikan salah satu nilai dasar untuk menggambarkan bahwa dalam kolaborasi ada sesuatu yang lebih pada hubungan antar aktor. Lebih lanjut, persoalan yang paling utama dalam komunikasi adalah kotennya. Hal yang menjadi pesan setidaknya terkait dengan curah pendapat dan berbagi informasi. Tirrel dan Clay (2010) menjadikan komunikasi sebagai salah satu indikator untuk menilai tingkatan kolaborasi. Tirrel dan Clay membagi tinggkatan kolaborasi menjadi 5 yaitu eksplorasi, formasi, tumbuh, dewasa dan akhir. Singkatnya, lintas pihak harus saling berkomunikasi langsung untuk menguatkan praktek collaborative governance.

4. Berbagi Sumber Daya, poin ini menjelaskan proses yang terjadi selama aksi collaborative governance.

Sumber daya yang dimaksud yakni sumber daya manusia dan sumber daya keuangan serta sumber daya lainnya yang dapat memperkuat aktfitas kolaborasi dalam kebijakan publik. Emerson dkk (2011) menempatkan sumber daya sebagai bagian dari variabel kapasitas. Kapasitas kolaborasi dapat dilihat pada sejauhamana sumber daya dibagi dan terbagi. Harapannya dengan cara itu, setiap kolaborator bisa saling menguatkan kelebihan dan menutupi kekurangan serta sama-sama aktif bertindak. Saling menguatkan dan saling menutupi, sebenarnya, esensi sebuah aktifitas kolaborasi. Pendekatan kolaborasi dilakukan untuk memudahkan pemecahan masalah publik. Harus diakui bahwa pemerintah memiliki kelebihan dan kelemahan, begitupun dengan swasta, media dan lembaga swadaya masyarakat. Kolaborasi hadir untuk menjawab adanya kekurangan sumber daya. Seringkali kekurangan sumber daya menjadi alasan tidak dilaksanakannya suatu pemecahan masalah. 
Kinerja lembaga sangat dipengaruhi oleh sumber dayanya (Lee dan Withford,

2012). Collaborative governance yang telah dijadikan strategi governance memang harus memperhatikan sumber daya dalam rangka penguatan kebijakan publik. Adanya pembagian sebagaimana yang diutarakan tentu akan menjadi kekuatan tersendiri. Sebagai tambahan, pengetahuan juga termasuk hal yang harus dibagi. Apabila kebutuhan sumber daya terpenuhi, dampak dari sebuah aksi kolaborasi akan lebih terasa. Sudah pasti kekuatan yang dimiliki oleh kolaborasi lebih baik dibanding aktivitas yang parsial. Sesuatu yang menyatu dan disatukan memiliki kekuatan tersendiri. Forum kolaborasi sudah menjadi milik bersama semua pihak yang terlibat. Oleh karena itu, tidak ada alasan untuk tidak membagi sumber daya yang dimiliki. Hasil yang baik akan meningkatkan reputasi pihak yang terlibat, sebaliknya hasil yang buruk akan menurunkan reputasi. Sudah pasti, kolaborasi hadir untuk memberikan warna yang lebih baik. Berbagai sumber daya menjadi salah satu penopangnya.

\section{KESIMPULAN}

Kompleksnya hubungan antara aktor dalam kebijakan publik melahirkan konsep baru yang dinamakan collaborative governance. Ringkasnya, collaborative governance adalah proses dan struktur yang melibatkan berbagai pihak melintasi batas-batas organisasinya. Kolaborasi digunakan untuk menggambarkan kerjasama yang formal, aktif, eksplisit dan berorientasi kolektif dalam manajemen dan kebijakan publik. Adapun nilai dasarnya yakni orientasi konsensus dalam pengambilan keputusan (tujuan), kepemimpinan kolektif dalam kelembagaan (struktur), komunikasi multiarah dalam hubungan kemanusiaan (interaksi) dan berbagi sumber daya dalam aksi (proses). Nilai dasar tersebut menjadi satu kesatuan yang terintegrasi pada setiap tahapan kebijakan publik.

\section{DAFTAR PUSTAKA}

Ansell, Chris, dan Gash, Alison. 2007. Collaborative Governance in Theory and Practice. Journal of Public Administration Research and Theory. Vol.18, hal.543-571. Diakses tanggal 29 November 2013. dari Oxford Journals (JPART). 
Ansell, Chris, dan Gash, Alison. 2007. Collaborative Governance in Theory and Practice. Journal of Public Administration Research and Theory Advance, Issue DOI : 208 10.1093/jopart/mum032. Source : OAI, hlm. 1-29.

Bevir, Mark. 2009. Key Concepts in Governance. New Delhi: Sage Publication.

Cline, K.D. 2000. Defining the Implementation Problem : Organizational Management versus Cooperation, Journal of Public Administration Research and Theory, Vol.10(3). hal.551-571. Diakses tanggal 20 Maret 2015. dari Oxford Journals (JPART).

Dwiyanto, A. 2011. Manajemen Pelayanan Publik : Peduli,Inklusif, dan Kolaboratif. Yogyakarta: Gadjah Mada University Press.

Emmerson, K, Nabatchi, T dan Balogh, S. 2011. An Integrative Framework for Collaborative Governance. Journal of Public Administration Research and Theory. Vol.22, hal.129. Diakses tanggal 29 November 2013. dari Oxford Journals (JPART).

Goliday, A. M. 2010. Identifying the Relationship Between Network Governance and Community Action Program Participation, Disertasi. Departement Public Policy and Administration. Walden University. Diakses tanggal 22 Agustus 2013. dari UMI Dissertations Publishing.

Johnston, dkk. 2010. Managing the Inclusion Process in Collaborative Governance. Journal of Public Administration Research and Theory. Vol.21, hal.699-721. Diakses tanggal 20 Maret 2015. dari Oxford Journals (JPART).

Jung, dkk. 2009. Collaborative Governance In The United States and Korea : Cases In Negotiated Policymaking and Service Delivery. Diakses dari www.bedrosian.usc.edu. 
Kurniawan, T. 2007. Pergeseran Paradigma Administrasi Publik : Dari Perilaku Model Klasik dan NPM Ke Good Governance. Jurnal Ilmu Administrasi Negara. 7 (1) : 16-17.

Lee, S. Y dan Withdrof, A.B. 2012. Assessing the Effects of Organizational Resources on Public Agency Performance : Evidence from the US Federal Government, Journal of Public Administration Research and Theory. Vol.23. hal.687-712. Diakses tanggal 20 Maret 2015. dari Oxford Journals (JPART).

Leo Agustino. 2008. Dasar-dasar Kebijakan Publik. Cet I Pebruari. Bandung: Alfabeta.

Martin dkk. 2008. Leadership, Service Reform, and Public-Service Networks : The Case of Cancer-Genetics Pilots in the English NHS. Journal of Public Administration Research and Theory. Vol.19. hal.769-794. Diakses tanggal 20 Maret 2015. dari Oxford Journals (JPART).

Osborne, Stephen. P. 2010. The New Public Governance? Emerging Perspective on The Theory and Practice of Public Governance. New York: Routledge.

Silvia, Chris. 2011. Collaborrative Governance Concepts for Succesful Network Leadership, State and Local Government Review. Vol. 43 (1). hal. 66-71. Diakses tanggal 27 Agustus 2013. dari SAGE Publication.

Wahab, Friedrich. 2004. Analisis Kebijakan dari Formulasi ke Implementasi Kebijaksanaan Negara. Jakarta: Bumi Aksara. 